TITLE:

\title{
Zinc-Catalyzed Synthesis of Acylsilanes Using Carboxylic Acids and a Silylborane in the Presence of Pivalic Anhydride
}

\section{$\operatorname{AUTHOR}(\mathrm{S}):$}

Tatsumi, Kenta; Tanabe, Sae; Tsuji, Yasushi;

Fujihara, Tetsuaki

\section{CITATION:}

Tatsumi, Kenta ...[et al]. Zinc-Catalyzed Synthesis of Acylsilanes Using Carboxylic Acids and a Silylborane in the Presence of Pivalic Anhydride. Organic Letters 2019, 21(24): 10130-10133

ISSUE DATE:

2019-12-20

URL:

http://hdl.handle.net/2433/261182

\section{RIGHT:}

This document is the Accepted Manuscript version of a Published Work that appeared in final form in Organic Letters, copyright $(\odot)$ American Chemical Society after peer review and technical editing by the publisher. To access the final edited and published work see https://doi.org/10.1021/acs.orglett.9b04151.; This is not the published version. Please cite only the published version.; この論文は出版社版でありません。引用の際には出版社版をご確認ご利用ください。 


\title{
Zinc-Catalyzed Synthesis of Acylsilanes Using Carboxylic Ac- ids and a Silylborane in the Presence of Pivalic Anhydride
}

\author{
Kenta Tatsumi, Sae Tanabe, Yasushi Tsuji, and Tetsuaki Fujihara* \\ Department of Energy and Hydrocarbon Chemistry, Graduate School of Engineering, Kyoto University, \\ Nishikyo-ku, Kyoto 615-8510, Japan.
}

\section{Supporting Information Placeholder}

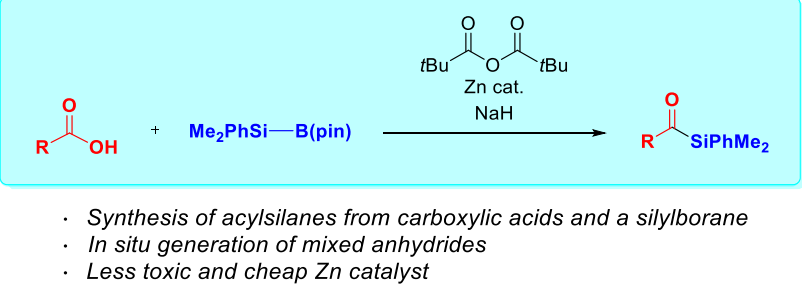

ABSTRACT: Zinc-catalyzed synthesis of acylsilanes using carboxylic acids and a silylborane has been achieved in the presence of pivalic anhydride. Various carboxylic acids were converted to the corresponding acylsilanes. The in situ formation of mixed anhydrides was essential in the present reaction.

Acylsilanes are carbonyl compounds in which silicone and oxygen atoms are directly bound to the same carbon atom. ${ }^{1}$ As a result of this unique feature, acylsilanes are very versatile and can be used in many organic transformations, such as reactions with various nucleophiles via Brook rearrangement, ${ }^{2}$ photochemical reactions, ${ }^{3}$ and transition-metal catalyzed reactions. ${ }^{4}$

Classically, acylsilanes are synthesized by silylation of lithiated 1,3-dithianes followed by a deprotection step. ${ }^{5} \mathrm{Al}-$ ternative preparation methods include the oxidation of organosilicon compounds.6,7 Direct synthesis of acylsilanes via silylation of carbonyl compounds using silyl metals such as lithium, ${ }^{8}$ magnesium, ${ }^{9}$ or aluminum ${ }^{10}$ species was also reported. However, functional group tolerance was quite low due to their high reactivity. Although silyl copper species provided acylsilanes with various functional groups, ${ }^{11}$ a stoichiometric amount of copper wastes was generated after the reaction.

In contrast to classical synthetic methods, transition metal-catalyzed preparation of acylsilanes using mild silylation reagents are highly reliable. Yamamoto reported the palladium-catalyzed synthesis of acylsilanes from acid chlorides and disilanes (Scheme 1a). ${ }^{12}$ Later, Riant reported that acylsilanes could be synthesized by the reaction of acid anhydrides with silylboranes in the presence of $\mathrm{Cu}$ catalysts (Scheme 1b).13 These methods result in various acylsilanes, however, the reaction starting materials, such as acid chlorides or acid an-

\section{Scheme 1. Transition Metal-Catalyzed Synthesis of Acylsilanes}

(a) Pd-catalyzed reaction using acid chlorides

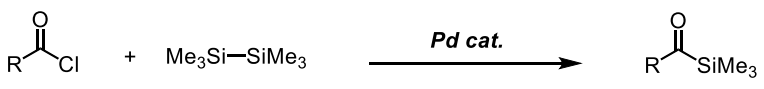

(b) Cu-catalyzed reaction using acid anhydrides

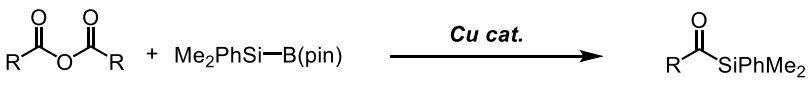

(c) Zn-catalyzed reaction using carboxylic acids (This Work)

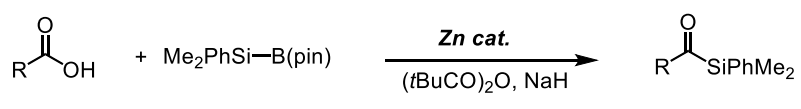

hydrides, must be prepared from the corresponding carboxylic acids before use. Herein, the Zn-catalyzed synthesis of acylsilanes using carboxylic acids and a silylborane is reported, where pivalic anhydride was found to be indispensable additive (Scheme 1c). The key to success of this reaction is the in situ formation of a mixed anhydride. ${ }^{14}$

First, sodium benzoate (1a-Na) was reacted with a silylborane, $\mathrm{PhMe} 2 \mathrm{Si}-\mathrm{B}(\mathrm{pin})$, using pivalic anhydride as an additive in the presence of a zinc catalyst in $1: 1(\mathrm{v} / \mathrm{v})$ $\mathrm{ClCH}_{2} \mathrm{CH}_{2} \mathrm{Cl} /$ toluene at $90{ }^{\circ} \mathrm{C}$ for $18 \mathrm{~h}$ (Table 1$) .15$ Without a zinc catalyst, the reaction did not proceed at all (entry 1). Employing $\mathrm{ZnCl}_{2}$ as the catalyst, an acylsilane (2a) was obtained in $76 \%$ GC yield (entry 2). $\mathrm{Zn}(\mathrm{OAc})_{2}$ was found to be less effective as the catalyst (entry 3 ), producing the product $2 \mathrm{a}$ in $66 \%$ yield, while $\mathrm{Zn}\left(\mathrm{O}_{2} \mathrm{CtBu}\right)_{2}$ showed high catalytic activity (entry 4). A commercially available ZnEt2 was also effective for the reaction, giving $\mathbf{2 a}$ in $86 \%$ yield (entry 5 ). Lithium benzoate (1a-Li) and potassium benzoate $(\mathbf{1 a}-\mathrm{K})$ were not effective substrates for the reaction (entries 6 and 7). In the case of benzoic acid (1a) as the substrate, the desired product was not detected at all (entry 8). On the other hand, in situ deprotonation using $\mathrm{NaH}$ dramatically improved the yield of $\mathbf{2 a}$ (entry 9). Under the reaction conditions, pure $\mathbf{2 a}$ was isolated in $82 \%$ yield. The Reaction using 2.0 mol of $1 a(0.24$ g) afforded $3 \mathbf{a}$ in $64 \%$ yield $(0.31 \mathrm{~g})$. Next, other catalysts were tested and $\mathrm{Pd}(\mathrm{OAc})_{2}, \mathrm{Cu}(\mathrm{OAc})$, and $\mathrm{AlCl}_{3}$ were found to be ineffective (entries 10-12). When other silyl sources such as Et 3 Si-B(pin) 
Table 1. Optimization of Reaction Conditions for $\mathrm{Zn}$ Catalyzed Synthesis of an Acylsilane $\mathbf{2 a}^{a}$

\begin{tabular}{|c|c|c|c|}
\hline \multicolumn{2}{|c|}{$\begin{array}{l}\begin{array}{l}\text { aa-M }(M=N a, K, L i) \\
\text { or } 1 a(M=H)\end{array} \\
\text { (M }=H e_{2} P h S i-B(p i n)\end{array}$} & $\begin{array}{l}\text { Catalyst }(5.0 \text { mol \%) } \\
(\text { tBuCO })_{2} \mathrm{O}(1.5 \text { equiv }) \\
\mathrm{ClCH}_{2} \mathrm{CH}_{2} \mathrm{Cl} / \text { toluene } \\
(1: 1,2.0 \mathrm{~mL}) \\
90^{\circ} \mathrm{C}, 18 \mathrm{~h}\end{array}$ & $\underbrace{O}_{2 a}$ \\
\hline entry & catalysts & M & yield of $\mathbf{2 a}(\%)^{b}$ \\
\hline 1 & none & $\mathrm{Na}$ & 0 \\
\hline 2 & $\mathrm{ZnCl} 2$ & $\mathrm{Na}$ & 76 \\
\hline 3 & $\mathrm{Zn}(\mathrm{OAc})_{2}$ & $\mathrm{Na}$ & 66 \\
\hline 4 & $\mathrm{Zn}\left(\mathrm{O}_{2} \mathrm{CtBu}\right)_{2}$ & $\mathrm{Na}$ & 86 \\
\hline 5 & ZnEt2 (1.0 M in hexan & $\mathrm{Na}$ & 86 \\
\hline 6 & $\mathrm{ZnEt}_{2}$ & $\mathrm{Li}$ & 56 \\
\hline 7 & $\mathrm{ZnEt}_{2}$ & $\mathrm{~K}$ & 13 \\
\hline 8 & $\mathrm{ZnEt}_{2}$ & $\mathrm{H}(\mathbf{1 a})$ & 0 \\
\hline $9^{c}$ & $\mathrm{ZnEt}_{2}$ & $\mathrm{H}(\mathbf{1 a})$ & $86(82)^{d}$ \\
\hline $10^{c}$ & $\mathrm{Pd}(\mathrm{OAc})_{2}$ & $\mathrm{H}(\mathbf{1 a})$ & 0 \\
\hline $11^{c}$ & $\mathrm{Cu}(\mathrm{OAc})$ & $\mathrm{H}(\mathbf{1 a})$ & 0 \\
\hline $12^{c}$ & $\mathrm{AlCl}_{3}$ & $\mathrm{H}(\mathbf{1} \mathbf{a})$ & 0 \\
\hline
\end{tabular}

${ }^{a}$ Reaction conditions: $1 \mathrm{a}(0.40 \mathrm{mmol}), \mathrm{Me}_{2} \mathrm{PhSi}-\mathrm{B}(\mathrm{pin})(0.52 \mathrm{mmol})$, catalyst $(0.020 \mathrm{mmol}, 5.0 \mathrm{~mol} \%),(t \mathrm{BuCO})_{2} \mathrm{O}(0.60 \mathrm{mmol})$ in $\mathrm{ClCH}_{2} \mathrm{CH}_{2} \mathrm{Cl} /$ toluene $(1: 1(\mathrm{v} / \mathrm{v}), 2.0 \mathrm{~mL})$ at $90{ }^{\circ} \mathrm{C}$ for $18 \mathrm{~h} .{ }^{b} \mathrm{GC}$ Yield by an internal standard method. ${ }^{c} \mathrm{NaH}$ (1.1 equiv) was added. ${ }^{d}$ Isolated yield of $\mathbf{2 a}$.

or $\mathrm{Me}_{3} \mathrm{Si}_{-} \mathrm{SiMe}_{3}$ were tested in place of $\mathrm{Me}_{2} \mathrm{PhSi}-\mathrm{B}$ (pin), the desired products were not obtained at all ${ }^{15}$.

Next, the substrate scope was examined using various carboxylic acids in the presence of $\mathrm{NaH}$ (Table 2). Aromatic carboxylic acids bearing electron-donating (1b and 1c) and electron-withdrawing groups $(\mathbf{1 d}-\mathbf{g})$ on the phenyl ring afforded the corresponding acylsilanes $(\mathbf{2 d - g})$ in moderate-togood yields (entries 1-6). In the reaction, bromo and iodo groups were intact (entries 4 and 5). A boronic ester moiety was also tolerated (entry 7). The reaction of a sterically hindered substrate (1i) was smoothly converted to the product (2i) in $80 \%$ yield (entry 8 ). 1-Naphthoic acid (1j) also gave the product (2j) in good yield (entry 9). Aliphatic carboxylic acids (1k-n) also afforded the corresponding products (2kn) (entries 10-13). Ester functional group in $\mathbf{1 m}$ was tolerated (entry 12). Cyclohexanecarboxylic acid (1n) also reacted with silylborane, giving $\mathbf{2 n}$ in moderate yield (entry 13). On the other hand, bulky pivalic acid 10 did not afford the corresponding product at all (entry 14). Other carboxylic acids having a chiral center at the $\alpha$ position such as $\mathrm{N}, \mathrm{N}$ dibutylalanine were not suitable substrates.

To obtain insights into the reaction mechanism, some control experiments were carried out (Scheme 2). When sodium benzoate (1a-Na) was reacted with $\mathrm{PhMe}_{2} \mathrm{Si}-\mathrm{B}(\mathrm{pin})$ in the absence of pivalic anhydride, the product $2 \mathbf{a}$ was not obtained at all (Scheme 2a). Thus, carboxylate was not directly silylated and the formation of a mixed anhydride by the reaction of 1a$\mathrm{Na}$ and pivalic anhydride (in equilibrium) is indispensable. Next, benzoic anhydride (3) as an alternative substrate for the mixed anhydride reacted with $\mathrm{PhMe}_{2} \mathrm{Si}-\mathrm{B}(\mathrm{pin})$. Although 2a was obtained, the yield was low (Scheme $2 \mathrm{~b}$ ). In order to gen-
Table 2. Scope of Carboxylic Acids for the Synthesis of Acylsilanes $^{a}$

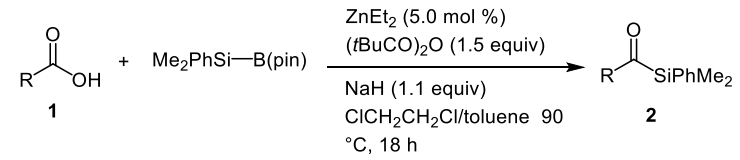

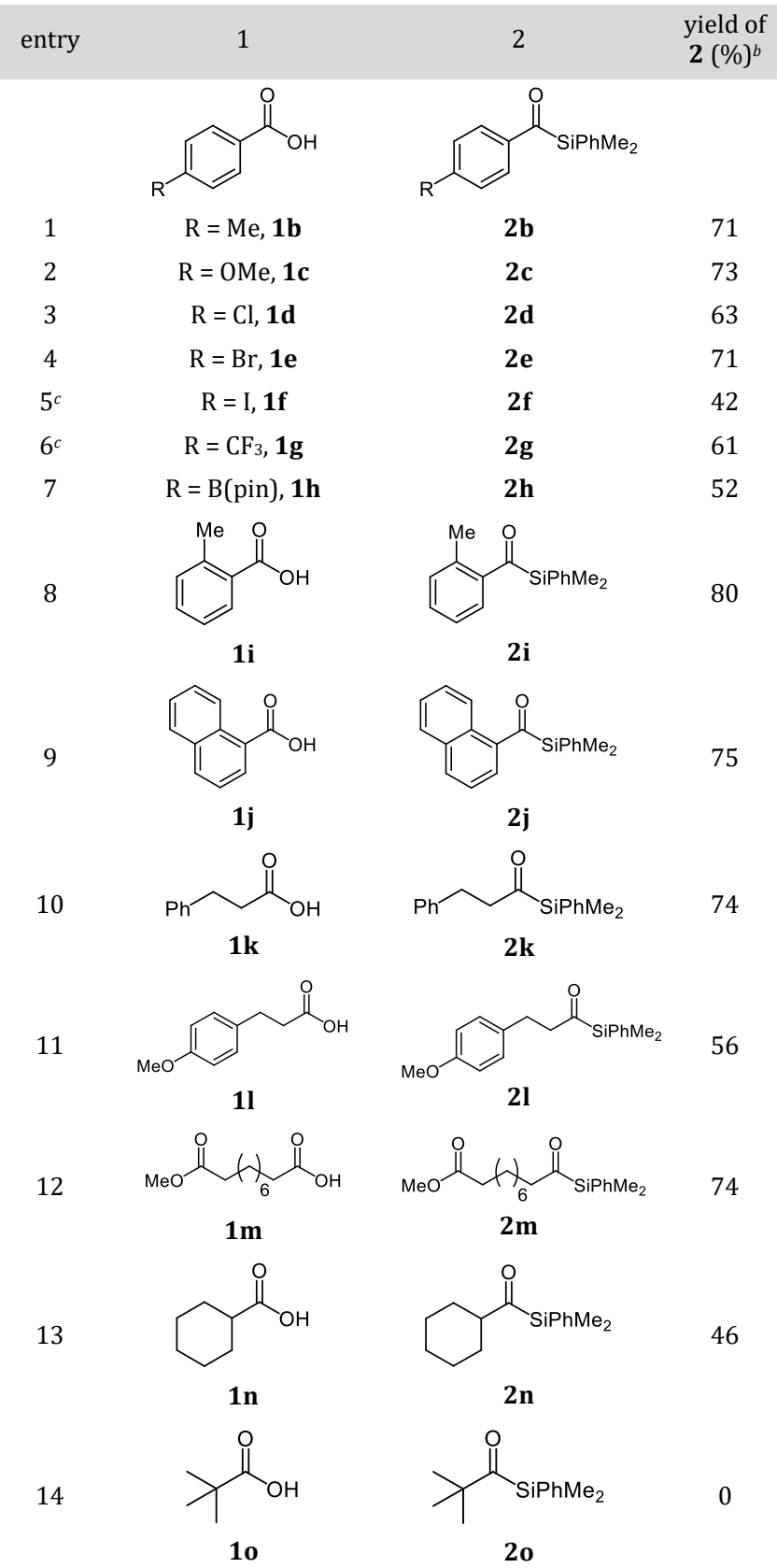

${ }^{a}$ Reaction conditions: $\mathbf{1}(0.40 \mathrm{mmol}), \mathrm{Me}_{2} \mathrm{PhSi}-\mathrm{B}(\mathrm{pin})(0.52 \mathrm{mmol})$, $\mathrm{ZnEt}_{2}(1.0 \mathrm{M}$ in hexane, $0.020 \mathrm{mmol}, 5.0 \mathrm{~mol} \%),(t \mathrm{BuCO})_{2} \mathrm{O}(0.60$ $\mathrm{mmol}), \mathrm{NaH}(0.44 \mathrm{mmol})$ in $\mathrm{ClCH}_{2} \mathrm{CH}_{2} \mathrm{Cl} /$ toluene $=1: 1(\mathrm{v} / \mathrm{v}, 2.0 \mathrm{~mL})$ at $90^{\circ} \mathrm{C}$ for $18 \mathrm{~h} .{ }^{b}$ Isolated yield of $2 .{ }^{c} 10 \mathrm{~mol} \%$ of $\mathrm{ZnEt}_{2}$ was used.

erate the mixed anhydride, sodium pivalate was added to the reaction with 3 (Scheme 2c). As a result, the yield of $\mathbf{2 a}$ was increased to $52 \%$ yield, indicating in situ generated mixed anhydride is a key intermediate for the present reaction. 
Scheme 2. Control Experiments to Elucidate the Reaction Mechanism. (a)

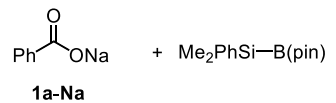

(b)<smiles>O=C(OC(=O)c1ccccc1)c1ccccc1</smiles>

(c) $3+\underbrace{\stackrel{\mathrm{O}}{\mathrm{ONa}}^{(1.0 \text { equ }}}_{\substack{\mathrm{Bu} \\ \text { (1.0 equiv) }}}+\mathrm{Me}_{2} \mathrm{PhSi}-\mathrm{B}(\mathrm{pin})$

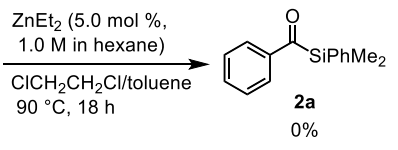

$\mathrm{ZnEt}_{2}(5.0 \mathrm{~mol} \%$

$\underset{\substack{\mathrm{ClCH}_{2} \mathrm{CH}_{2} \mathrm{Cl} / \text { toluene } \\ 90{ }^{\circ} \mathrm{C}, 18 \mathrm{~h}}}{\stackrel{1.0 \mathrm{M}}{\longrightarrow}} \quad \underset{25 \%}{2 \mathrm{a}}$

$\mathrm{ZnEt}_{2}(5.0 \mathrm{~mol} \%$,

$1.0 \mathrm{M}$ in hexane)

$90{ }^{\circ} \mathrm{C}, 18 \mathrm{~h}$
$2 a$

$52 \%$
A plausible catalytic cycle for the reaction discovered in this work is presented in Scheme 3. First, $\mathrm{ZnEt}_{2}$ reacts with pivalic anhydride, giving zinc carboxylate $\mathbf{A}$. Next, transmetalation with silylborane affords silylzinc intermediate $\mathbf{B}$, which was recently reported by Uchiyama. ${ }^{16}$ Then, $\mathbf{B}$ reacts with insitu generated mixed anhydride $\mathbf{C}$ to afford an intermediate $\mathbf{D}$. In this step, B selectively reacts with a less hindered carbonyl group in $\mathbf{C}$ due to the bulky $t \mathrm{Bu}$ group. Such steric difference is important for site selectivity. ${ }^{14}$ Finally, an elimination step results in the formation of product 2 and the zinc carboxylate species regenerates. Considering what is outlined in Scheme 2c, an in-situ generated sodium carboxylate may support the transmetalation step (step a).

In conclusion, a zinc compound was found to catalyze the reaction of carboxylic acids with a silylborane in the presence of pivalic anhydride. The reactions yielded the corresponding acylsilanes in moderate-to-high yields. Further studies on the reaction mechanism and the application of the principles of this study to other silylation reactions are currently underway.

\section{ASSOCIATED CONTENT}

\section{Supporting Information}

Experimental procedures and characterization of the products. This material is available free of charge via the Internet at http://pubs.acs.org.

\section{AUTHOR INFORMATION}

\section{Corresponding Author}

tfuji@scl.kyoto-u.ac.jp

\section{Notes}

The authors declare no competing financial interests.

\section{ACKNOWLEDGMENT}

This work was supported by JSPS KAKENHI Grant Number 18H04257 in Precisely Designed Catalysts with Customized Scaffolding (TF), and 17H03096 in Grant-in-Aid for Scientific Research B (YT) from MEXT, Japan. TF also acknowledged Tokuyama Science Foundation for financial supports.

\section{REFERENCES}

(1) For a review, see: Zhang, H.-J.; Priebbenow, D. L.; Bolm, C. Chem. Soc. Rev. 2013, 42, 8540-8571, and references cited therein.
Scheme 3. A Plausible Catalytic Cycle

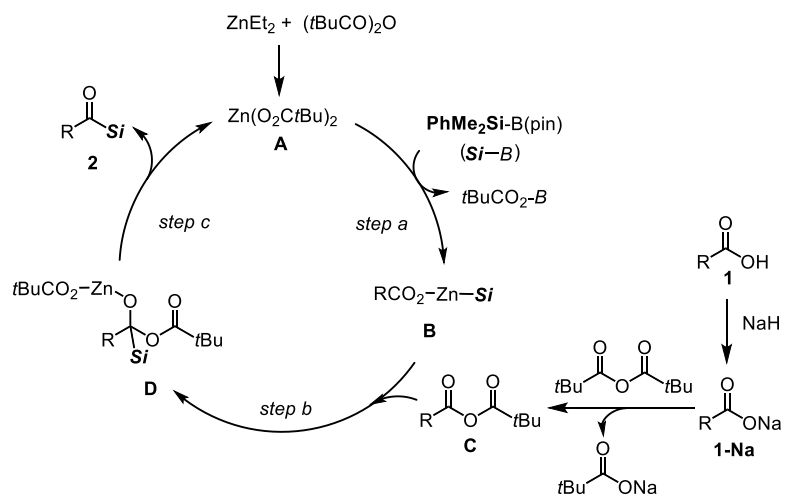

(2) For selected examples, see: (a) Reich, H. J.; Rusek, J. J.; Olson, R. E. J. Am. Chem. Soc. 1979, 101, 2225-2227. (b) Kuwajima, I.; Kato, M. J. Chem. Soc., Chem. Commun. 1979, 708-709. (c) Takeda, K.; Fujisawa, M.; Makino, T.; Yoshii, E.; Yamaguchi, K. J. Am. Chem. Soc. 1993, 115, 9351-9352. (d) Takeda, K.; Nakajima, A.; Takeda, M.; Okamoto, Y.; Sato, T.; Yoshii, E.; Koizumi, T.; Shiro, M. J. Am. Chem. Soc. 1998, 120, 4947-4959. (e) Lettan II, R. B.; Galliford, C. V.; Woodward, C. C.; Scheidt, K. A. J. Am. Chem. Soc. 2009, 131, 8805-8814. (f) Unger, R.; Weisser, F.; Chinkov, N.; Stanger, A.; Cohen, T.; Marek, I. Org. Lett. 2009, 11, 1853-1856. (g) Sasaki, M.; Kondo, Y,; Kawahata, M.; Yamaguchi, K.; Takeda, K. Angew. Chem., Int. Ed. 2011, 50, 6375-6378. (h) Priebbenow, D. L. J. Org. Chem. 2019, 84, 11813-11822.

(3) (a) Ito, K.; Tamashima, H.; Iwasawa, N.; Kusama, H. J. Am. Chem. Soc. 2011, 133, 3716-3719. (b) Zhang, H.-J.; Becker, P.; Huang, H.; Pirwerdjan, R.; Pan F.-F. Bolm, C. Adv. Synth. Catal. 2012, 354, 21572161. (c) Ishida, K.; Tobita, F.; Kusama, H. Chem. Eur. J. 2018, 24, 543546.

(4) (a) Obora, Y.; Ogawa, Y.; Imai, Y.; Kawamura, T.; Tsuji, Y. J. Am. Chem. Soc. 2001, 123, 10489-10493. (b) Schmink, J. R.; Krska, S. W. J. Am. Chem. Soc. 2011, 133, 19574-19577.

(5) (a) Brook, A. G.; Duff, J. M.; Jones, P. F.; Davis, N. R. J. Am. Chem. Soc. 1967, 89, 431-434. (b) Corey, E. J.; Seebach, D.; Freedman, R. J. Am. Chem. Soc. 1967, 89, 434-436.

(6) (a) Reich, H. J., Eisenhart, E. K. J. Org. Chem. 1984, 49, 52825283. (b) Linderman, R. J.; Suhr, Y. J. Org. Chem., 1988, 53, 1569-1572. (c) Lipshutz, B. H.; Lindsley, C.; Susfalk, R.; Gross, T. Tetrahedron Lett. 1994, 35, 8999-9002. (d) Reddy, G. P.; Reddy, J. S.; Das, S.; Roisnel, T.; Yadav, J. S.; Chandrasekhar S.; Gre'e, R. Org. Lett. 2013, 15, 1524-1527.

(7) (a) Hassner, A.; Soderquist, J. A. J. Organomet. Chem. 1977, 131, C1-C4. (b) Brook, A. G.; J. Am. Chem. Soc. 1957, 79, 4373-4275. (c) Corriu, R. J. P.; Masse, J. P. J. Organomet. Chem. 1970, 22, 321-332. (d) Degl'Innocenti, A.; Walton, D. R. M; Seconi, G.; Pirazzini, G.; Ricci, A. Tetrahedron Lett. 1980, 21, 3927-3928. (e) Cossrow, J.; Rychnovsky, S. D. Org. Lett. 2002, 4, 147-150. (f) Inoue, A.; Kondo, J.; Shinokubo, H. Oshima, K. J. Am. Chem. Soc. 2001, 123, 11109-11110. (g) Kondo, J.; Shinokubo, H.; Oshima, K. Org. Lett. 2006, 8, 1185-1187.

(8) (a) Fleming, I.; Ghosh, U. J. Chem. Soc., Perkin Trans. 1994, 1, 257-262. (b) Clark, C. T.; Milgram, B. C.; Scheidt, K. A. Org. Lett. 2004 6, 3977-3980.

(9) Picard, J. P.; Calas, R.; Dunogues, J.; Duffaut, N.; Gerval J.; Lapouyade, P. J. Org. Chem. 1979, 44, 420-424.

(10) (a) Kang, J.; Lee, J. H.; Kim, K. S.; Jeong, J. U.; Pyun, C. Tetrahedron Lett. 1987, 28, 3261-3262. (b) Nakada, M.; Nakamura, S.-I.; Kobayashi, S.; Ohno, M. Tetrahedron Lett. 1991, 32, 4929-4932.

(11) (a) Bonini, B. F.; Comes-Franchini, M.; Mazzanti, G.; Ricciand A.; Sala, M. J. Org. Chem., 1996, 61, 7242-7243. (b) Bonini, B. F.; Comes-Franchini, M.; Fochi, M.; Laboroi, F.; Mazzanti, G.; Ricci, A.; Varchi, G. J. Org. Chem. 1999, 64, 8008-8013.

(12) (a) Yamamoto, K.; Suzuki, S.; Tsuji, J. Tetrahedron Lett. 1980, 21, 1653-1656. (b) Yamamoto, K.; Hayashi, A.; Suzuki, S.; Tsuji, J. Organometallics 1987, 6, 974-979. (c) Geng, F.; Maleczka, R. E. Tetrahedron Lett. 1999, 40, 3113-3114.

(13) Cirriez, V.; Rasson, C.; Riant, O. Adv. Synth. Catal. 2013, 355, $3137-3140$. 
(14) For the reactions using pivalic anhydride, see: (a) Nagayama, K.; Shimizu, I.; Yamamoto, A. Chem. Lett. 1998, 1143-1144. (b) Nagayama, K.; Shimizu, I.; Yamamoto, A. Bull. Chem. Soc. Jpn. 2001, 74, 1803-1815. (c) Gooßen, L. J.; Ghosh, K. Angew. Chem., Int. Ed. 2001, 40, 3458-3460. (d) Gooßen, L. J.; Ghosh, K. Chem. Commun. 2002, 836837. (e) Fujihara, T.; Cong, C.; Terao, J.; Tsuji, Y. Adv. Synth. Catal. 2013, 355, 3420-3424. (f) Pan, F.; Lei, Z, -Q.; Wang, H.; Li, H.; Sun, J. Shi, Z. -J.
Angew. Chem., Int. Ed. 2013, 52, 2063-2067. (g) Maetani, S.; Fukuyama, T.; Ryu, I. Org. Lett. 2013, 15, 2754-3219.

(15) See Supporting Information for details.

(16) Nagashima, Y.; Yukimori, D.; Wang, C.; Uchiyama, M. Angew. Chem., Int. Ed. 2018, 57, 8053-8057. 